\title{
Effects of institutional quality and the development of the banking system on corporate debt
}

\author{
Alvaro Edmundo Tresierra and Sergio David Reyes \\ Faculty of Economics and Business, Universidad de Piura, Piura, Peru
}

\begin{abstract}
Purpose - This study aims to determine if the quality of national institutions and banking development condition the maturity of debt depending on the horizon of short or long term.

Design/methodology/approach - Analysis is performed on a sample of 116 nonfinancial companies from Peru and Brazil. The measures of quality of national institutions and banking development were obtained from World Bank data and included factorial analysis for dynamic considerations.

Findings - The findings, through the treatment of pointed indicators, the factor analysis and the subsequent estimation of a dynamic econometric model, called GMM-SYS, show that institutional quality fosters the maturity of long-term debt and banking development boots short-term financial relations.

Research limitations/implications - Evaluating different measures of the quality of national institutions and banking development is necessary to demonstrate the robustness of the results beyond the sample evaluated in Latin America.

Practical implications - The research allows to understand the interaction between national institutions and system banking through debt maturity, and this is useful for establishing common target between both groups.

Social implications - It is important for corporate finance to understand the mechanisms of the interaction between national institutions and system banking, because this affects internal decisions of firms regarding financial implications.

Originality/value - The treatment of measures of national institutions and banking development include dynamic considerations, and the application of this study in Latin America provides new findings regarding these kind of indexes and their interaction with firms" features such as debt maturity.
\end{abstract}

Keywords Stock market, Banking system, Factorial analysis, GMM-SYS, Institutionality, Maturity of debt

Paper type Research paper

\section{Introduction}

Currently, the analysis of the characteristics of debt has achieved greater connotation in the study of corporate finance, in response to the need to achieve a greater understanding of what type of factors are involved and how these influence and affect the decision-making of financing in the business activity, given the implications that such decisions may have on the liquidity and solvency of the company. In this scenario, the maturity of debt represents a

(C) Alvaro Edmundo Tresierra and Sergio David Reyes. Published in Journal of Economics, Finance and Administrative Science. Published by Emerald Publishing Limited. This article is published under the Creative Commons Attribution (CC BY 4.0) licence. Anyone may reproduce, distribute, translate and create derivative works of this article (for both commercial and non-commercial purposes), subject to full attribution to the original publication and authors. The full terms of this licence may be seen at http://creativecommons.org/licenses/by/4.0/legalcode 
JEFAS

23,44

114

determining variable regarding how the times of the financial obligations are assumed, which in parallel represents an indicator of the activity itself, because short- or long-term obligations will be preferred under the internal or external characteristics.

This acquires greater significance if we take it to specific realities such as Latin America, where despite the economic relevance and the growth of financial markets, the evidence on this issue is scarce. With this precedent, this study focuses on the diversity of financial, social and cultural relations of Latin American countries for the construction of indexes of institutional quality and banking development that allow measuring how some factors, external to the company, influence the decision-making on the maturity of debt, which in turn has implications for business development, insofar as this is a product, in a significant way, of a specific institutional climate.

Emphasizing on the importance of this type of studies on the Latin American region, it should be noted that, for our case, Peru and Brazil represent economies with high levels of development, and they differ in terms of business and institutional issues. However, despite these differences, it is possible to confirm that the indexes of institutional quality and development of the banking system are determining factors in the maturity of debt, and that this, beyond the geographical reality studied, is linked to specific external factors to a company that sometimes are not explicitly considered by economic agents, but that underlie the structure of corporate capital.

In this established direction, this study has built a theoretical framework around the maturity of debt that consolidates two large groups of variables: the first refers to own or internal company's characteristics and the second refers to indicators of institutional quality and development of the banking system. The fundamental contributions of this research are as follows: the degree of institutional quality achieved by each country affects the dynamics of the relationships between companies and investors through the effectiveness and obligatory nature of a legal framework, and the development of the banking system, constituted as a source of information, has a preponderant role in the proximity of the relations between economic agents at the moment of making corporate decisions related to debt.

The paper has been structured as follows: Section 2 presents a review of the existing literature; Section 3 presents the objectives and hypotheses; Section 4 describes data exposure, methodological framework and econometric considerations; Section 5 states the results; and Section 6 concludes the paper.

\section{Literature review}

The dynamics that allows companies to make decisions about their financial structure has been widely studied on the basis of elementary approaches where it is linked to the stability of cash flows (Modigliani and Miller, 1958) until reaching scenarios in which factors external to a company largely determine its financial performance. This is based on the recognition of rights and contracts that bind investors and creditors through the possession of assets on which agents determine limits that optimally distribute control (Hart, 1995). The relationship described does not have a unique nature, as the existence of companies and institutions with multiple characteristics has allowed the emergence of societies with very different rules and legal frameworks. Depending on the rights of shareholders and creditors, the degree of obligation of the law and the structure of ownership, these legal frameworks condition the corporate decisions of companies (La Porta et al., 1998). In that direction, the interaction generated from the meeting of economic agents around capital brings imperfections that are the product of conflict of interests and asymmetric information, which in turn restrict the ability of the market to grant financing to a company (Demirguc-Kunt 
and Maksimovic, 1999). This is linked to the development and effectiveness of the legal framework, in addition to the financial system. In the case of the latter, the reference extends to the fact that intermediaries in financial markets are generators of information and elements that serve as a signal or guarantee for investors' decision-making so that their degree of development becomes a determinant of economic growth (King and Levine, 1993).

Considering this diversity of links, studies around legal, financial and social traditions in different countries have shown that the quality of the relationship that a corporate company maintains with its investors conditions its debt (Antoniou et al., 2006) so that the internal development of the company and institutional characteristics such as leverage, volatility of income and liquidity (relative to liquidity risk), opportunities for growth or size (in reference to the agency theory), business quality (relative to the theory of signals) and performance of the actions have a direct relationship with the nature of this type of debt and the profitability and level of activity of the stock market or concentration of property, at the institutional level, have the same significant effect (Deesomsak et al., 2009).

In addition, banking concentration and the quality of the financial system have been weighted as fundamental within heterogeneous legal frameworks, as in the Latin American case (Gonzales and Gonzales, 2008), where - in addition to institutional quality - significant variables are considered in its relationship with corporate debt (Kirch and Soares, 2012). It is even possible to determine which specific institutional forces such as government quality, rule of law or financial development are directly linked (Fan et al., 2011).

Despite the extensive literature surrounding the financial structure and corporate debt, the treatment has been unique with respect to its nature, focusing on the level of leverage, without observing underlying variables of the internal structure of the debt, such as its maturity or source. In this effort, it is necessary to quote recent studies such as those by Davydov (2016) or O'Connor and Yaghoubi (2016), who managed to link maturity of debt to variables such as profitability of the company and volatility of cash flows. Thus, beyond empirical considerations, a consensus has been reached regarding the role of debt maturity (as a specific internal characteristic of the financial structure) in the mitigation of agency costs (Childs et al., 2005) and the definition of the corporate organizational structure (Anderson et al., 2003).

Based on the previous review, this study defines the maturity of debt as a term of the obligation that a corporate company decides for the return of the borrowed money. On this variable, we seek to provide solid evidence of how factors external to the company specifically indicators of institutional quality and development of the banking system affect its short- or long-term nature, focusing on a little studied reality such as that of Latin America, where the diversity of cultural characteristics associated with the company and the finances allow for a more extensive study, which in our case focuses on Peru and Brazil.

\section{Hypotheses}

The development of the financial system for Peru and Brazil, focused on the banking system, shares common characteristics; indicators such as banking rate, concentration, patrimonial backing and risk level describe a bank structure of an emerging economy. Likewise, similar macroeconomic features in both countries are identified, such as the free flotation of the exchange rate, monitored by the competent institutions of monetary policy or the free market of interest rates. These shared elements validate the fact of studying together banking development in both economies. As described, it should be added that most banks have diversified short-term products and services (for the cases studied), adjusting them to the overdraft financing requirements, promissory notes, letter discounts, etc. All the above validates the approach of the following hypothesis: 
JEFAS

23,44

116

H1. The development of the banking system promotes the financial leverage of corporate companies in relation to short-term products and services.

On the other hand, with regard to institutional quality and according to indicators recently reported by the World Bank, we see that Peru and Brazil have similar scores (with Brazil slightly above) and hold average positions (taking Latin America as a reference). Thus, it can be inferred that the two countries exhibit shared characteristics around the structure of government, regulative framework, social and democratic stability, citizen participation, etc. It should be added that on average, countries of the area have an average institutional quality with a tendency to improve (achieving greater stability, better governance structures, efficient regulatory frameworks, etc.) throughout the period studied, which characterizes the emerging economies. Thus, we hypothesize the following hypothesis:

H2. The institutional quality promotes the financial leverage of corporate companies in relation to the long term.

\section{Methodology and data}

In this section, we describe the data and methodological structure used in this research.

\subsection{Determinants of maturity of debt}

The determinants of the maturity of corporate debt can be grouped into variables related to the company's performance and variables related to the macro-financial context of a country. The first set of variables comprises leverage (Myers, 1977; Fosu et al., 2016, Castro et al., 2016), company size (Barnea et al., 1980; Awartani et al., 2015; Gonzales, 2015), growth opportunities (Myers, 1977; Yung et al., 2015; Gonzales, 2015), profitability (Demirguc-Kunt and Maksimovic, 1999; An et al., 2016; Zhang, 2016), business risk (Kane et al., 1985; Laeven et al., 2015; Košak et al., 2015), tangibility (Demirguc-Kunt and Maksimovic, 1999; Stephan et al., 2011; Gungoraydinoglu and Oztekin, 2011) and regulated industry (Barclay and Smith, 1996), defining the following (Table I).

It can be seen that the relationship. between variables resulting from business performance and the maturity of debt is explicit throughout the previous literature; however, on the aggregate elements in terms of country, there is a recent research that states, for example, that an effective legal system encourages long-term investments (Demirguc-Kunt and Maksimovic, 1999; Nasr et al., 2015; Alves and Francisco, 2015). These

\begin{tabular}{ll}
\hline Var. explic. & Formula \\
\hline Leverage & Book value debt/Business market value \\
Size of the company & Ln (Sales) \\
Growth oppurtunities & (S. bks. liab. + S. eq. mkt.)/(Tot. bks. ass.) \\
Profitability & Ebit/T. bks. ass. \\
Tangibility & Net fixed ass./T. bks. ass. \\
Business risk & Std. dev. of profitability \\
Inflation volatility & Std. dev. of the annual inf. rate per country \\
Ref. rate volatility & Std. dev. of the ref. rate per country \\
Regulated industry* & 1 if business belongs to: Const., Elect., Gas and oil, Mining; Telec., y Transp. y \\
& Logist, 0 in other case.
\end{tabular}

Table I.

Source: Own elaboration 
authors argue that it is feasible for businesses to engage credibly with banking, controlling the opportunistic behavior of corporate information, so much so that the factors of institutional quality, banking development, volatility of the reference rate and volatility of inflation (Kirch and Soares, 2012) are considered as macro-financial variables.

In contrast, Fan et al. (2012) consider that in a country with a weak legal system and a low-level of institutional quality, the financial system should make to prevailing products that allow the creditor to have less discretion and easier interpretation. Demirguc-Kunt and Maksimovic (1999) further argue that the existence of active, developed and large financial markets should facilitate long-term capital growth.

\subsection{Data and variables}

In selecting the sample universe, the Economatica database was used, where financial information was obtained from 116 companies (observation unit) between 2004 and 2014 for Peru and Brazil. In total, 1,276 observations were recorded. International Monetary Fund statistics were used to collect information on interest rates and inflation.

It should be noted that this analysis does not include financial sector companies, as they have a different decision-making structure; similarly, those with negative equity, or a longterm debt ratio between total debt and long-term liabilities on total negative liabilities, are not analyzed. Complementarily, the econometric estimates have been restricted by the availability of continuous data throughout the period studied. With these restrictions, the sample consisted of 81 Brazilian companies and 35 Peruvian companies; Brazil contributed about 69 per cent of the data.

In addition, the treatment of the dependent variable, maturity of the debt, has presented serious limitations in the recording of the financial information of the various companies analyzed. Therefore, a proxy variable that allowed pairing with the natural definition of maturity was constructed. This is also referred to in studies by Kirch and Soares (2012) and is measured as long-term financial debt over total debt (maturity of debt); in contrast, a dependent variable defined as short-term financial debt was generated on total financial debt (short-term debt) to assess whether the exogenous determinants examined have a similar effect on the financing of different horizons.

Regarding the descriptive statistics of the main variables, it was observed that Brazil had a higher maturity ratio of corporate debt than Peru (0.62 and 0.53, respectively; opposite situation for the short-term debt variable). In this direction, the variables leverage and size of the company presented ratios of 0.88 and 12.42 for the Brazilian case and 0.66 and 11.82 for the Peruvian case, respectively. This allows us to infer that Brazilian companies assume a greater proportion of debt and are also larger.

In contrast, the ratios of the variables opportunities of growth, profitability and tangibility present better performances for the Peruvian case than for the Brazilian case; for example, the ratio of growth opportunities for Peru reaches 3.18, while for Brazil, it is 1.40. Thus, it can be inferred that the 35 companies in the Peruvian case have greater expansion projections compared to their Brazilian counterpart.

In addition, according to the price index of each country, Peru presents a greater volatility of macroeconomic components such as the reference rate for banking transactions and the rate of inflation; here, 68 per cent of Peruvian companies are regulated, that is, they belong to the construction, electricity, gas, oil, mining, telecommunications, transportation and logistics sectors, whereas only 49 per cent of Brazilian companies are regulated (Table II). 


\begin{tabular}{llrr} 
JEFAS & \multicolumn{2}{c}{} & Average \\
\cline { 2 - 4 } 23,44 & Variables & Peru & \multicolumn{1}{c}{ Brazil } \\
\cline { 2 - 4 } & Maturity of the debt & $0.540(0.32)$ & $0.63(0.28)$ \\
& Short-term debt & $0.460(0.32)$ & $0.374(0.28)$ \\
& Leverage & $0.668(1.42)$ & $0.88(2.38)$ \\
$\mathbf{1 1 8}$ & Company size & $11,828(1.52)$ & $12.42(3.28)$ \\
& Growth opportunities & $3,810(5.93)$ & $1.41(0.90)$ \\
& Profitability & $0.104(0.083)$ & $0.09(0.11)$ \\
& Business risk & $0.569(0.38)$ & $0.7289(0.48)$ \\
& Tangibility & $0.484(0.22)$ & $0.09(0.23)$ \\
& Inflation volatility & $0.259(0.05)$ & $0.002(0.0005)$ \\
& Ref. rate volatility & $0.461(0.58)$ & $0.10(0.02)$ \\
& Regulated industry* & 0.686 & 0.49
\end{tabular}

Table II Notes: *Dycotomic variable, 1 if regulated; 0 otherwise. Std. dev. between parentheses. In Peru and Brazil, there are 385 and 891 observations, respectively

Descriptive statistics Source: Own elaboration

\subsection{Factorial analysis}

Performing factor analysis on indicators of interest is supported by the fact that many investigations do not recognize that there is an explicit relation between different components, taking isolated measures from them (invariants over time) and increasing the probability of bias for omitted variables (refer to Kirch and Soares, 2012, for details).

The factors representative of banking development and quality of institutions have been constructed on the basis of a wide set of indices from the databases "Financial Structure" and "Indicators of governability", both from the World Bank. Thus, continuous and variant factors between 2004 and 2013 were obtained. As the information is only available up to the last year mentioned, a linear projection of the components of each resulting factor was carried out with the aim of expanding the study base until 2014. It should be noted that the addition did not drastically alter the distribution, dispersion and composition of the data.

At this point, the indicators that define the generation of factors for the institutional quality are voice and responsibility, political stability, government effectiveness, regulatory quality, rule of law and corruption control, while in the case of the banking development factor, the following were taken into account:

- assets of the central bank between the more active central bank money deposits, liquidity of liabilities between PBI;

- deposits of banks between PBI;

- private loans for deposit banks between PBI;

- private credit by deposit banks and other financial institutions between PBI;

- bank deposits between PBI;

- deposits of the financial system between PBI;

- bank loans between bank deposits;

- liquidity of liabilities;

- bank overheads between total assets;

- intermediation margin, bank ROA and bank ROE; and

- outstanding loans from nonresident banks between PBI. 
Once the factorial analysis was defined, for the case of institutional quality, Brazil stands out over Peru with a governance index of 0.08 ; likewise, in the case of the banking development factor, it can be concluded that Brazil has a stronger development than Peru in this sector (-0.49 and -1.02 , respectively); in an aggregate way, the Brazilian case has better indicators than the Peruvian case (Table III).

\subsection{Econometric model}

The research presents two statistical specifications to measure the relationships between the interest variables. The first one presents a linear relationship between dependent and independent variables, on which fixed effects and random effects estimations will be applied to control the invariant and variant components over time, as the case may be, by aggregate characteristics for each country, sector and company. Thus:

$$
Y_{i t}=a_{i}+x_{i t} B+e_{i t}
$$

where $Y_{i t}$ is the dependent variable of interest for $i$ at time $t ; a_{i}$ is a constant; $x_{i t}$ is the set of independent co-variables; $B$ is the estimated impact of them; and $e_{i t}$ is the error on which assumptions for the case of fixed effects and random effects are made.

On the other hand, the inclusion of the endogenous leverage variable requires the application of dynamic specifications and estimates. This new estimation methodology, called GMM-SYS, uses first differences as instruments for the equations mitigating the bias produced by the level variables with the nature of weak instruments for the first difference equations. In summary, the dynamic model presents greater advantages than the simple use of a static model, as it allows the treatment of the lag of the dependent variable as explanatory variable, besides taking into account the problems of endogeneity, which are defined as:

$$
M D_{i t}=B_{0}+a M D_{i t-1}+a_{2} \text { Leverage }_{i t}+B_{1 k} X_{i k t}+B_{2 l} Z_{i l t}+v_{i}+e_{i t}
$$

where $M D_{i t}$ is the time-dependent variable $t$ and for individual $i$ (maturity of the company's debt; in contrast, we can also refer to the short-term debt variable); Leverage $e_{i t}$ is the leverage ratio, which is considered endogenous in the model; $X_{i k t}$ represents the company's default variable $k$; $Z_{i l t}$ represents the $l$ exogenous variables; $v_{i}$ represents the specific unobserved effects of the firms and is constant with time; and $e_{i t}$ represents the idiosyncratic error term.

In this type of dynamic model, different reasons for correlation in the maturity regression of debt over time are shown, first directly through $M D_{i t}$ with previous

\begin{tabular}{lcrr}
\hline & & Average & \\
Variables & Peru & \multicolumn{1}{c}{ Brazil } \\
\hline Bank development & $-1.025(0.11)$ & & $-0.499(0.15)$ \\
Institutional quality & $-0.252(0.07)$ & & $0.080(0.08)$
\end{tabular}

Notes: Std. dev. between parentheses. In Peru and Brazil, there are 385 and 891 observations, respectively Source: Own elaboration

Table III. Factor analysis 
JEFAS 23,44

periods, then through exogenous observable co-variables $X_{i k t}$ and finally through the time-invariant effects of individual $v_{i}$, defined as unobserved heterogeneity.

\section{Results and discussion}

In this section, we examine the results obtained from the different econometric specifications established; it should be noted that in the case of the short-term debt, only the dynamic model estimates are presented, as the fixed and random effects approach is not relevant in the case of statistical significance and it does not keep the direction of the expected impact.

For the case of the maturity of the debt, we can observe, through the estimation of fixed and random effects, that the variables banking development and institutional quality have a positive impact on it, which coincides with the expected scenario. Thus, it is assumed that the institutional quality of the legal, social and economic framework fostered by governmental and private entities has an impact on the decision to assume long-term financial obligations, while the degree of development of the banking system, measured in the diversity of components considered in the banking system, could be affecting the adoption of long-term debt. However, this cannot be strictly maintained, as it is necessary to consider dynamic relationships that allow us to observe how the decision-making on maturity is affected by historical performance. (Table IV).

Under the latter, the estimation is presented by GMM-SYS, which considers dynamic relations between exogenous and dependent variables, as well as lags of the endogenous leverage variable, defined as such, as it is assumed in conjunction with the maturity of the debt (in a way that is affected by similar elements). Thus, it is possible to conclude that at a significance level of 5 per cent, there is a positive impact of the institutional quality factor over the maturity of the long-term debt, while the banking development factor has a negative effect on the same variable of interest; in contrast, for the variable short-term debt, the determinants evaluated have an inverse relationship; the banking development factor has a positive impact and the institutional quality factor has a negative effect. All of the above can be exposed under certain considerations of

\begin{tabular}{lcrrrrr}
\hline & \multicolumn{7}{c}{ Dependent variable "maturity of corporate debt" } \\
Variables & RE (1) & RE (2) & RE (3) & FE (1) & FE (2) & FE (3) \\
\hline Leverage & $0.003(0.00)$ & $0.004(0.00)$ & $0.003(0.00)$ & $0.004(0.00)$ & $0.004(0.00)$ & $0.004(0.00)$ \\
Company size & $0.001(0.01)$ & $0.001(0.01)$ & $0.000(0.01)$ & $-0.005(0.01)$ & $-0.005(0.01)$ & $-0.006(0.01)$ \\
Growth opportunities & $0.002(0.00)$ & $0.003(0.00)$ & $0.002(0.00)$ & $0.004(0.00)$ & $0.004(0.00)$ & $0.004(0.00)$ \\
Profitability & $0.023(0.15)$ & $0.022(0.15)$ & $0.033(0.15)$ & $-0.012(0.08)$ & $-0.009(0.08)$ & $0.000(0.08)$ \\
Business risk & $-0.023(0.05)$ & $-0.023(0.05)$ & $-0.024(0.05)$ & & & \\
Tangibility & $0.054(0.05)$ & $0.041(0.05)$ & $0.059(0.05)$ & $0.013(0.05)$ & $0.004(0.05)$ & $0.020(0.05)$ \\
Regulated industry & $0.011(0.04)$ & $0.009(0.04)$ & $0.011(0.04)$ & & & \\
Ref. rate volatility & $-0.007(0.02)$ & $0.006(0.02)$ & $-0.002(0.02)$ & $0.007(0.02)$ & $0.020(0.02)$ & $0.011(0.02)$ \\
Inflation volatility & $0.000(0.16)$ & $-0.012(0.14)$ & $0.037(0.15)$ & $0.182(0.19)$ & $0.231(0.20)$ & $0.212(0.20)$ \\
Institutional quality & & $0.179 *(0.09)$ & $0.079(0.11)$ & & $0.156^{*}(0.07)$ & $0.084(0.08)$ \\
Bank development & $0.136^{*}(0.06)$ & & $0.114(0.07)$ & $0.112^{* *}(0.04)$ & & $0.089(0.05)$ \\
$\mathrm{N}^{\circ}$ of observations & 1,271 & 1,271 & 1,271 & 1,271 & 1,271 & 1,271
\end{tabular}

Table IV. Initial regressions results
Notes: Std. dev. between parentheses; for random effects estimations - (1), (2) and (3) - exists significance joint at $5 \%$; $p<0.05 ; * * p<0.01 ; * * * p<0.001$

Source: Own elaboration 
previous studies among which the impact of these factors on the maturity of long-term debt has been defined, but not in the short term. It is felt, then, that a developed banking system, with a high level of credit placement and intermediation, as well as a diversity of financial products, preferentially attends the short-term needs of corporate companies, responding to activities and investments that require high liquidity. Contrasting this with the financial statements of the units of analysis, we can observe the presence of accounts with denominations such as "promissory notes" and "overdrafts", among others, products highly related to the previously exposed liquidity needs.

The expressed argument goes to the factor that describes the quality of institutions, arguing that when government and private agents make up a stable, efficient, democratic regulatory framework with free association, transparent political measures, absence of violence, quality public services of legal rules and control of corruption, long-term corporate obligations are encouraged. This is because it allows a more stable and prolonged relationship between companies and financial agents, given that there is a context that does not alter the nature of agreements or contracts between stakeholders.

In the case of the exogenous variables included, in relation to the estimates on the maturity of the debt, it can be observed that the size of the company has a positive relation with the long-term financing; similarly, if the company is in a regulated industry, long-term obligations are also positively affected; in the opposite hand, if there is greater volatility of inflation, leverage and tangibility, the maturity of corporate debt decreases, whereas if the short-term debt is taken as the dependent variable, the relationships are inverse (Table V).

\section{Conclusions}

After the estimation of the dynamic model using GMM-SYS, it is possible to determine a significant and opposite effect of institutional quality and bank development on the maturity of long-term debt (or short-term, depending on the horizon of evaluation); so that it can be concluded that these macroeconomic factors, related to the degree of development of each country, condition the corporate decisions to adopt financial obligations, for the companies that are listed in the stock markets of Peru and Brazil. There is evidence that a stable, democratic, transparent and effective social, legal and economic framework in the application of standards fosters confidence among financial actors, fostering obligations with a long-term maturity; while a banking system with high penetration, volume of placements, diversity of products, numerous relationships among its agents and also extensive, prompts companies to be financed in the short term, attending to particular needs requiring high liquidity, on which the banks have a preference by offering alternatives for easy interpretation and adoption.

In addition, the study provides useful tools for the analysis of how a banking structure joined to quality institutions affects corporate decision-making in opposite ways, and this is relevant for the adoption of government and private policies that seek the maturity of shortand long-term debt, according to the objective.

Finally, the interest of the investigation can be extended to a comprehensive evaluation of the financial system and inclusion of more countries in the sample. However, it is necessary to emphasize that the diversity of business sectors subsequently requires a disaggregated analysis that allows a closer approximation to the process of corporate decision-making. 
JEFAS

23,44

122

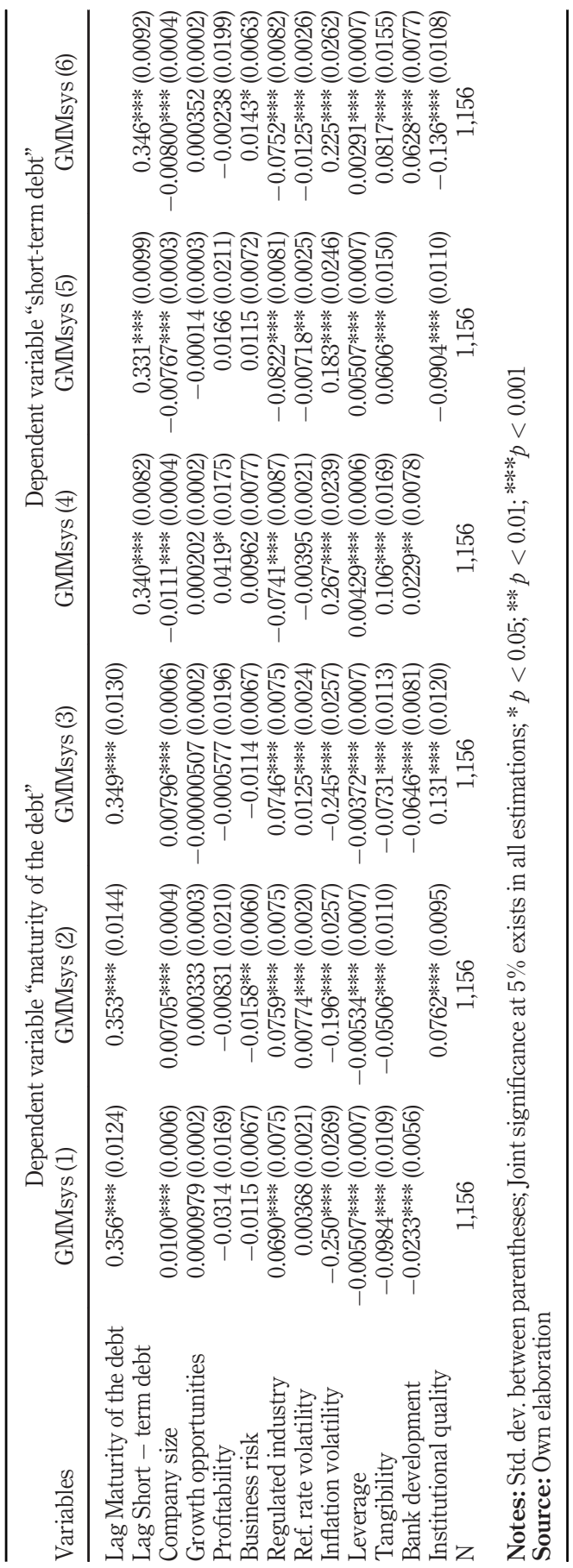

Table V.

Dynamic model results 


\section{References}

Alves, P. and Francisco, P. (2015), "The impact of institutional environment on the capital structure of firms during recent financial crises", The Quarterly Review of Economics and Finance, Vol. 57, pp. 129-146.

An, Z., Li, D. and Yu, J. (2016), "Earnings management, capital structure, and the role of institutional environments", Journal of Banking \& Finance, Vol. 68, pp. 131-152.

Anderson, R., Mansi, S. and Reeb, D. (2003), "Founding family ownership and the agency cost of debt", Journal of Financial Economics, Vol. 68 No. 2, pp. 263-285.

Antoniou, A., Guney, Y. and Paudyal, K. (2006), "The determinants of debt maturity structure: evidence from France, Germany and the UK", European Financial Management, Vol. 12 No. 2, pp. 161-194.

Awartani, B., Belkhir, M., Boubaker, S. and Maghyereh, A. (2015), "Corporate debt maturity in the MENA region: does institutional quality matter?", International Review of Financial Analysis, Vol. 46, pp. 309-325.

Barclay, M. and Smith, C.W. Jr (1996), "On financial architecture: leverage, maturity, and priority", Journal of Applied Corporate Finance, Vol. 8 No. 4, pp. 149-167.

Barnea, A.N., Hauguen, R.A. and Senbet, L.W. (1980), "A rationale for debt maturity structure and call provisions in the agency theoretic framework", Journal of Finance, Vol. 35 No. 5, pp. 1223-1234.

Castro, P., Tascón, M., Amor, B. and De Miguel, A. (2016), “Target leverage and speed of adjustment along the life cycle of European listed firms", Business Research Quarterly, Vol. 19 No. 3, pp. 188-205.

Childs, P., Mauer, D. and Ott, S. (2005), "Interactions of corporate financing and investment decisions: the effects of agency conflicts", Journal of Financial Economics, Vol. 76 No. 3, pp. 667-690.

Davydov, D. (2016), "Debt maturity and corporate performance in emerging markets", Research of International Business and Finance, Vol. 38, pp. 299-311.

Deesomsak, R., Paudyal, K. and Pescetto, G. (2009), "Debt maturity structure and the 1997 Asian financial crisis", Journal of Multinational Financial Management, Vol. 19 No. 1, pp. $26-42$.

Demirguc-Kunt, A. and Maksimovic, V. (1999), "Institutions, financial markets, and firm debt maturity", Journal of Financial Economics, Vol. 54 No. 3, pp. 295-336.

Fan, J.P.H., Wei, J.K.C. and Xu, X. (2011), "Corporate finance and governance in emerging markets: a selective review and agenda for future research", Journal of Corporate Finance, Vol. 17 No. 2, pp. 207-214.

Fan, J.P.H., Titman, S. and Twite, G. (2012), "An international comparison of capital structure and debt maturity choices", Journal of Financial and Quantitative Analysis, Vol. 47 No. 1, pp. 23-56.

Fosu, S., Danso, A., Ahmad, W. and Coffie, W. (2016), "Information asymmetric, leverage and firm value: do crisis and growth matter?", International Review of Financial Analysis, Vol. 46, pp. 140-150.

Gonzales, V.M. (2015), “The financial crisis and corporate debt maturity: the role of banking structure”, Journal of Corporate Finance, Vol. 35, pp. 310-328.

Gonzales, V.M. and Gonzales, F. (2008), "Influence of bank concentration and institutions on capital structure: new international evidence”, Journal of Corporate Finance, Vol. 14 No. 4, pp. 363-375.

Gungoraydinoglu, A. and Oztekin, O. (2011), "Firm - and country - level determinants of corporate leverage: some new international evidence", Journal of Corporate Finance, Vol. 17 No. 5, pp. 1457-1474.

Hart, S. (1995), "A natural - resource based view of the firm”, The Academy of Management Review, Vol. 20 No. 4, pp. 986-1014.

Kane, A., Marcus, A.J. and McDonald, R.L. (1985), "Debt policy and the rate of return premium to leverage", Journal of Financial Quantitative Analysis, Vol. 20 No. 4, pp. 479-499.

King, R. and Levine, R. (1993), "Finance, entrepreneurship, and growth: theory and evidence", Journal of Monetary Economics, Vol. 32 No. 3, pp. 513-542. 
JEFAS 23,44

Kirch, G. and Soares, P. (2012), "Determinats of corporate debt maturity in South America: do institutional quality and financial development matter?", Journal of Corporate Finance, Vol. 18 No. 1, pp. 980-993.

Košak, M., Li, S., Loncarski, I. and Marinc, M. (2015), "Quality of bank capital and bank lending behavior during the global financial crisis”, International Review of Financial Analysis, Vol. 37, pp. 168-183.

La Porta, R., Lopez de Silanes, F., Shleifer, A. and Vishny, R. (1998), "Law and finance”, The Journal of Political Economic, Vol. 106 No. 6, pp. 1113-1155.

Laeven, L., Ratnovski, L. and Tong, H. (2015), "Bank size, capital, and systemic risk: some international evidence", Journal of Banking \& Finance, Vol. 1, pp. S25-S29.

Modigliani, F. and Miller, M. (1958), "The cost of capital, corporation finance and the theory of investment", The American Economic Review, Vol. 48 No. 3, pp. 261-297.

Myers, S. (1977), "Determinants of corporate borrowing”, Journal of Financial Economics, Vol. 5 No. 2, pp. $147-175$.

Nasr, H., Boubaker, S. and Rouatbi, W. (2015), "Ownership structure, control contestability, and corporate debt maturity", Journal of Corporate Finance, Vol. 35, pp. 265-285.

O'Connor, K.Y. and Yaghoubi, M. (2016), "The influence of cash flow volatility on capital structure and the use of debt of different maturities", Journal of Corporate Finance, Vol. 38, pp. 18-36.

Stephan, A., Talavera, O. and Tsapin, A. (2011), "Corporate debt maturity choice in emerging financial markets", The Quarterly Review of Economics and Finance, Vol. 51 No. 2, pp. 141-151.

Yung, K., Diane, D. and Jian, Y. (2015), "The value of corporate financial flexibility in emerging countries", Journal of Multinational Financial Management, Vols 32-33, pp. 25-41.

Zhang, S. (2016), "Institutional arrangements and debt financing", Research in International Business and Finance, Vol. 36, pp. 362-372.

\section{Further reading}

Cai, K., Fairchild, R. and Yilmaz, G. (2007), "Debt maturity structure of Chinese companies", PacificBasin Finance Journal, Vol. 16, pp. 268-297.

\section{Corresponding author}

Sergio David Reyes can be contacted at: sergio.reyes@udep.pe

For instructions on how to order reprints of this article, please visit our website: 